Дмитро Вітер, доктор філософських наук., старший науковий співробітник, Національний університет оборони України імені Івана Черняховського ORCID ID 0000-0002-7330-1280

Володимир Оліферук, кандидат технічних наук, Національний університет оборони України імені Івана Черняховського

ORCID ID 0000-0002-0722-7561

Сергій Горбачевський, кандидат технічних наук, старший науковий співробітник Національний університет оборони України імені Івана Черняховського ORCID ID 0000-0001-8890-1580 DOI: $10.33099 / 2617-1775 / 2021-01 / 56-63$

\title{
Оцінювання спроможностей військових організаційних структур (методичне забезпечення інституційного огляду вищих військових навчальних закладів)
}

У статті розглянуто питання методичного забезпечення оцінювання спроможностей військових організачійних структур. Сучасний розвиток Збройних Сил України, пов'язаний з необхідністю відстоювати територіальну иілісність держави, враховуючи реалізацію стратегічного курсу на євроатлантичну інтеграцію, кардинально змінив пріоритет побудови ЗС Украӥни та базував нові завдання перед офіцерами та військовими спеціалістів. Зміна форм та методів ведення бойових дій, транзит ЗС Украӥни до стандартів НАТО, що потребує внесення змін до системи освіти та підготовки офіщерів та військових спеціалістів. Крім того розглянуто перспективи законодавства та нормативного регулювання концепції прочесу розвитку військової освіти в Украӥні. Аргументувалась необхідність внесення змін до чинного законодавства та нормативних актів у рамках нових завдань та закликів, щэо виникають перед Збройними Силами Украйни, та пріоритетів, які визначаються зовнішньополітичним курсом держави на євроатлантичну інтеграціюю. Представлені пропозиції щзодо формування концепції розвитку військової освіти в Украӥні, яка базується на стандартах та підходах, яких досягає держава - член НАТО. Інтереси національної безпеки та оборони, потреби виникнення та розвитку збройних конфліктів на державній території з боку Збройних Сил Украӥни постійно забезпечують відповідальність. Обгрунтована відповідь на зміну форм і методів ведення бойових дій, їх характеру, основних принципів та загальних змін у навколишньому середовищі. У цъьому контексті важливим науковим завданням $\epsilon$ адекватна оцінка відповідальності Збройних Сил Украӥни в иілому та відповідальності військових організащійних структур. Вирішення изього потребує в очүінці відповідальності сучасної методичної розробки.

Ключові слова: військова організачійна структура, інституційний огляд, методика, очінювання, спроможності Збройних Сил.

Постановка проблеми. Інтереси національної безпеки i оборони, які пов’язані із запобіганням виникненню та розвитку збройних конфліктів на території держави, із забезпеченням ії здатності протистояти зовнішній агресії, 
вимагають від Збройних Сил України (далі - ЗС України) постійно підтримувати та нарощувати спроможності, що має на меті забезпечення здатності протидіяти наявним i потенційним загрозам i небезпекам, ураховувати зміни, що відбуваються у збройних силах противника, завчасно й адекватно реагувати на зміни форм і способів ведення збройної боротьби, іiі характеру, основних принципів, урахування загальних змін в безпековому, стратегічному і операційному середовищі. У цьому контексті адекватна оцінка спроможностей $3 \mathrm{C}$ України в цілому та спроможностей військових організаційних структур зокрема $\epsilon$ важливим науковим завданням, розв'язання якого потребує розроблення методичного забезпечення оцінювання спроможностей.

Аналіз останніх досліджень i публікацій. Питання розроблення методики оцінки організаційних структур, їх ефективності та оптимізації досліджували А. Рєзчіков, С. Смірнов, А. Цвіркун, В. Кушніков, В. Іващенко, які звертають увагу переважно на потенційні можливості застосування методів математичного моделювання. При цьому у центрі уваги більшості досліджень міститься питання оцінки організаційних структур цивільних інституцій. Водночас питання розробки методики оцінювання спроможностей військових організаційних структур залишається актуальним.

Метою статі $\epsilon$ висвітлення пропозицій до методики оцінювання спроможностей військових організаційних структур для методичного забезпечення інституційного огляду.

Виклад основного матеріалу. Складовою частиною методики є загальні положення, в яких розкриваються основні принципи, на яких грунтується методика. Зокрема, у загальних положеннях визначається, що методика визначає порядок організації та проведення оцінювання спроможностей військових організаційних структур (далі - ВОС) на управлінському рівні (оцінка управління), систему показників та критеріїв, механізм формування експертної оцінки.

Законодавчим та нормативно-правовим підгрунтям методики є: Закон України "Про освіту", Закон України "Про вищу освіту", "Положення про акредитацію освітніх програм, за якими здійснюється підготовка здобувачів вищої освіти” (Наказ МОН України № 977 від 11.07.2019р.), наказ МОУ від 09.01.2020 № 4 "Про затвердження Положення про особливості організації освітньої діяльності у вищих військових навчальних закладах Міністерства оборони України та військових навчальних підрозділах закладів вищої освіти", рішення НАЗЯВО, протокол № 9 від 29.08.2019 р.) [1-5].

Методика передбачає застосування системи показників та груп критеріїв оцінки управління (за напрямами та видами діяльності). Розподіл критеріїв здійснюється відповідно основним функціям управління (планування, організація, мотивація, контроль) за рівнями реалізації компонентів управлінської діяльності (адміністративний, фінансово-економічний, соціальнопсихологічний, особистісно-орієнтований).

Основною частиною методики є послідовність проведення оцінки. У запропонованій методики оцінка управління на основі оцінки спроможностей 
передбачає декілька основних етапів (Рис. 1), на яких експерти оцінюють повноту реалізації функцій планування, організації (координації), мотивації та

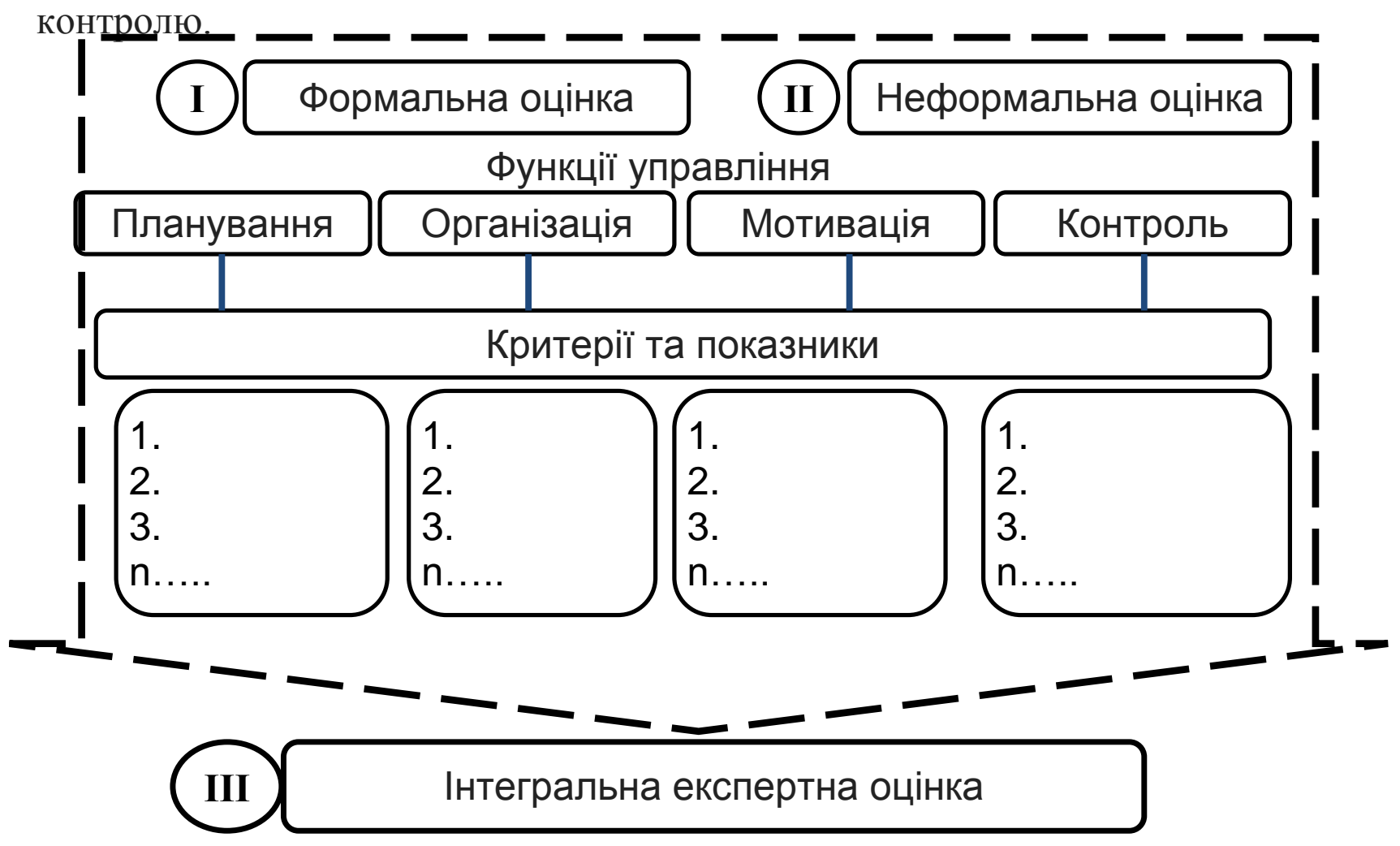

Рис. 1. Етапи оцінки управління на основі спроможностей

Перший етап оцінки передбачає опрацювання експертами відповідних документів, що розроблені для реалізації цілей управління (формальна оцінка).

Оцінка стану управління. Під час перевірки стану управління елементами оцінювання є стан організації діяльності та забезпечення його якості; кадрове, інформаційне, матеріально-технічне забезпечення діяльності тощо.

Стан планування діяльності оцінюється на основі встановлення рівня якості опрацювання основних документів, які регламентують організацію та забезпечення діяльності (відповідно до вимог діючої нормативно-правової бази). До основних документів можуть належать статути, положення, стандарти, професійні стандарти, плани основних заходів за напрямами та розділами (наприклад, матеріально-технічне (логістичне) забезпечення) тощо; наявності та якості опрацювання основних документів підрозділу, які регламентують організацію та забезпечення діяльності (плани основних заходів, тощо).

Стан організації діяльності оцінюється на основі контролю якості опрацювання основних документів (статути, положення, організаційноштатний розклад, функціонали тощо).

Оцінка мотивації здійснюється на основі контролю якості опрацювання основних документів (наприклад, положення про організацію діяльності, накази по особовому складу (заохочення, стягнення) тощо).

Оцінка контролю здійснюється на основі контролю якості опрацювання основних документів. 
Стан організації освітньої діяльності оцінюється на основі визначення наявності у вищому військовому навчальному закладі (далі - ВВНЗ) ліцензії на провадження освітньої діяльності за спеціальностями та рівнями вищої освіти; сертифікатів про акредитацію освітніх програм за всіма спеціальностями; стандартів вищої освіти для кожного ступеня вищої освіти за кожною спеціальністю (копії); професійних стандартів за кожною спеціальністю; наявності й дії у ВВНЗ системи забезпечення якості освіти; в наявності освітньо-кваліфікаційних характеристик (кваліфікаційних вимог) за спеціальностями; навчальних програм тощо.

Стан навчально-методичного забезпечення підготовки змінного складу (особового складу підрозділу) оцінюється на основі визначення наявності у ВВНЗ освітньо-професійних (освітньо-наукових, професійних) програм для кожного рівня освіти за кожною спеціальністю; навчальних (робочих) планів; робочих програм навчальних дисциплін, навчально-методичних матеріалів; методичних вказівок, інших навчально-методичних матеріалів, зміст яких відповідає робочим програмам навчальних дисциплін; визначення відповідності навчально-методичних матеріалів за кожною спеціальністю програмам підготовки.

Стан інформаційного забезпечення оцінюється на основі встановлення визначення рівня забезпеченості виданнями відповідного або спорідненого спеціальності профілю; довідковою та іншою навчальною літературою, визначеною робочими програмами навчальної дисципліни, у тому числі в електронному вигляді; особовий склад має доступ до Інтернету як джерела інформації та баз даних.

Під час перевірки стану навчальної роботи ВВНЗ елементами оцінювання є: стан організації та проведення навчальних занять; стан організації самостійної роботи курсантів (слухачів, студентів, ад’юнктів); стан організації практичної підготовки курсантів (слухачів, студентів, ад’юнктів). При цьому стан організації та проведення навчальних занять оцінюється за відповідності проведення навчальних занять розкладу занять за видами, визначеними робочими програмами навчальних дисциплін, навчальними програмами, організованих 3 використанням сучасних технологій навчання; визначення відповідності навчальних занять (не менше ніж у 75\%), які перевірялись, методів проведення навчальних занять їх видам, дотримання рекомендованих методичних розробок методикам проведення занять, методичного рівня керівника, проведення занять на встановлених об'єктах матеріально-технічної бази.

Стан методичної роботи оцінюється за рівнем організації та проведення засідань вчених (методичних, педагогічних) рад ВВНЗ та їх структурних підрозділів; навчально-методичних (методичних) зборів, нарад; інструкторськометодичних занять; доповідей 3 питань методики навчання, загальної та військової педагогіки; організації проведення педагогічних (методичних) експериментів, вивчення та реалізація в освітньому (навчально-виховному) процесі вимог керівних документів, передового педагогічного досвіду та узагальнення досвіду підготовки та застосування військ (сил); систематичності 
проведення підвищення кваліфікації й методичної майстерності керівного складу, науково-педагогічних (педагогічних) працівників, інструкторськовикладацького складу.

Стан кадрового забезпечення оцінюється на основі встановлення рівня відповідності кадрового забезпечення спеціальностей підготовки ліцензійним умовам; рівня кадрового забезпечення спеціальностей підготовки військових фахівців забезпечує якість навчання, інструкторсько-викладацький склад має відповідний рівень військової освіти за кожною військово-обліковою спеціальністю, який визначається наказами Міністерства оборони України (далі - МО) та Генерального штабу ЗС України (далі - ГШ ЗС України). При цьому рівень кадрового потенціалу оцінюється за загальною чисельністю особового складу i працівників у структурних підрозділах ВВН3 та відповідності чисельності нормам та вимогам керівних документів. Рівень підготовки особового складу визначається за рівнем індивідуальної підготовки постійного складу, змінного складу, підрозділів забезпечення навчального процесу та оцінюється за рівнем індивідуальної підготовки. Рівень індивідуальної підготовки постійного складу визначається за рівнем підвищення кваліфікації, навчальним навантаженням інструкторсько-викладацького складу, рівнем підготовки органу управління. Рівень підвищення кваліфікації, навчального навантаження перевіряється відповідно до вимог чинного законодавства, наказів і директив МО й оцінюється на основі аналізу планової роботи 3 підвищення кваліфікації постійного складу; відповідності навчального навантаження інструкторсько-викладацького складу встановленим вимогам.

Стан мотивації діяльності оцінюється за рівнем забезпечення соціальноекономічних, побутових, інших потреб особового складу, стану психологічного клімату, задоволеності стилем і методами керівництва, стимулювання професійного зростання і підвищення кваліфікації тощо.

Стан морально-психологічного забезпечення перевіряється відповідно до вимог чинного законодавства України, наказів, директив МO, Головнокомандувача ЗС України, ГШ ЗС України. Стан психологічного забезпечення перевіряється за такими показниками: організація проведення соціально-психологічного діагностування; стан психологічної підготовки; організація проведення соціально-психологічного супроводу.

Оцінювання морально-психологічного стану особового складу, рівня авторитету та лідерства командирів проводиться відповідно до визначених наказів МО і ГШ ЗС України.

Оцінка контролю управління діяльністю здійснюється на основі встановлення рівня підготовки органу управління (штабу), результатів практичної роботи органу військового управління (штабу) на навчаннях (тренуваннях) та станом індивідуальної підготовки офіцерського складу й оцінюється відповідно до оцінки органу військового управління, військової частини.

Оцінка управління матеріальними ресурсами здійснюється шляхом оцінки дотримання вимог керівних документів організації матеріальнотехнічної бази за місцем постійної дислокації та польової навчальної бази. Так, 
для ВВНЗ стан навчально-матеріальної технічної бази за місцем постійної дислокації оцінюється як такий, що відповідає вимогам, якщо площа навчальних приміщень становить не менш 2,4 кв. м на одну особу фактичного контингенту осіб, які навчаються та не менше 30\% приміщень оснащені мультимедійним обладнанням; наявність, стан, утримання й оснащення озброєння військової техніки та тренажерів становить не менш 70\% загальної кількості, визначених у штаті (табелю до штату) ВВН3 та забезпечує діяльність відповідно до професійних, освітньо-професійних (освітньо-наукових), навчальних програм; забезпеченість навчальних, лабораторних, житлових, допоміжних, санітарно-технічних, складських, підсобних приміщень, клінічної, спортивної, загальновійськової бази, обладнання та устаткування $\epsilon$ обгрунтованою та достатньою для провадження освітньої діяльності, проведення навчально-виховного процесу. Стан польової навчальної бази перевіряється й оцінюється відповідно до вимог наказів, директив МО та ГШ ЗС України.

Другий етап реалізації методики передбачає проведення експертної оцінки шляхом опитування (неформальна оцінка). На цьому етапі експерти проводять опитування, ураховуючи відомості самооцінювання особового складу (постійного та змінного складу у випадку ВВНЗ), адміністративного персоналу тощо, які надаються підчас опрацювання опитувальних листів. Опитувальний лист містить у собі уточнювальні запитання, які стосуються оцінки управління діяльністю та матеріальними ресурсами, необхідні для формування загального експертного висновку. Система показників та критеріїв експертної оцінки може бути сформованою на основі діючих нормативів $[4 ; 6 ; 7]$.

Третій етап передбачає формування загального експертного висновку за кожною окремою функцією управління діяльністю та матеріальними ресурсами. Висновок містить інтерпретацію результатів оцінювання за формальною та неформальною оцінками (за двома етапами оцінювання), їх узагальнення та ухвалення рішення щодо удосконалення управління діяльністю та матеріальними ресурсами.

Висновки. Надані пропозиції до методики оцінювання спроможностей ВОС можуть бути використані у процесі вдосконалення методичного забезпечення проведення інституційного аудиту професійної військової освіти у ВВН3, які перебувають у сфері управління МО України, адже зазначений аудит покликаний проаналізувати існуючий стан справ, оцінити, як організований освітній процес у системі професійної військової освіти, i наскільки задовольняє нагальні потреби сил оборони в контексті гібридних загроз національній безпеці та інтеграції України до НАТО.

Перспективи подальших досліджень пов’язані 3 виробленням комплексного підходу до методичного забезпечення оцінки організації діяльності та структурної організації ВОС, управлінського процесу та кадрового менеджменту, оцінки управління матеріальними ресурсами тощо. 


\section{ЛІТЕРАТУРА}

1. Закон України “Про вищу освіту” від 1 липня 2014 року № 1556-VII зі змінами. - URL: www.rada.zakon.gov.ua.

2. Закон України "Про освіту" від 5 вересня 2017 року № 2145-VIII. URL: www.rada.zakon.gov.ua.

3. Наказ МО України № 4 від 09.01.2020 “Про затвердження Положення про особливості організації освітньої діяльності у вищих військових навчальних закладах Міністерства оборони України та військових навчальних підрозділах закладів вищої освіти". - URL: www.mil.gov.ua.

4. Наказ МОН України № 977 від 11.07.2019 р. “Положення про акредитацію освітніх програм, за якими здійснюється підготовка здобувачів вищої освіти". - URL: www.mil.gov.ua.

5. Наказ МО України від 14.08.2020 року № 283 “Про організацію виконання окремих заходів оборонної реформи на середньострокову перспективу”. - URL: www.mil.gov.ua.

6. Збірник документів і матеріалів за напрямом "Функціональні групи спроможностей та Єдиний перелік (каталог) спроможностей Міністерства оборони України, Збройних Сил України та інших складових сил оборони" / Зб. док. і мат-лів. - К.: МО України, 2019. - 703 с.

7. Методичні рекомендації для експертів Національного агентства щодо застосування Критеріїв оцінювання якості освітньої програми (Рішення НАЗЯВО, протокол № 9 від 29.08.2019 p.). - URL: www.naqa.gov.ua.

Dmitry Viter, Dr. (Philosophical sciences), senior researcher National Defense University of Ukraine named after Ivan Cherniakhovskyi Vladimir Oliferuk

$\mathrm{PhD}$ (technical sciences)

National Defence University of Ukraine named after Ivan Cherniakhovskyi

Serhii Horbachevsky,

$\mathrm{PhD}$ (technical sciences), Senior Researcher National University of Defence of Ukraine Named after Ivan Chernyakhovskyi

\section{Assessment of the military organizational structures' responsibilities (methodical ensuring for institutional review of the high military education institutions)}

Introduction. The question about methodical ensuring of the military organizational structures' responsibilities assessment considered. Contemporary development of the Armed Forces of Ukraine connected with necessity to defend territorial wholeness of the state considering the realization of the strategic course to Euro-Atlantic integration, radically changed the priority of $A F$ of Ukraine building, and based the new tasks before officers and military specialists. The change of forms and methods of warfighting, transit of AF of Ukraine to NATO's standards needing the making changes in the system of education and training of the officers and military specialists. 
Purpose. The proposals for the methodic of responsibilities assessment of military organizational structure forming in aspect of the methodical ensure the institutional review.

Methods. The system of general scientific and special methods of theoretical and empirical research (analysis of scientific literature, systematization and generalization of materials, logic and comparative, content analysis) was used in order to realize the article purpose.

Results. The perspectives of law and normative regulation of the conception of the military education development process in Ukraine are considered. The necessity of making a changes to existing law and normative acts within a new tasks and callings that arises before Armed Forces of Ukraine, and priorities which determined by the foreign-political course of the state to Euro-Atlantic integration, argued. The proposals for forming the conception of the military education development in Ukraine that based on the standards and approaches which achieves in the state-members of NATO, represented. Interests of national safety and defense, needs of arising and development of the armed conflicts on the state territory needs from Armed Forces of Ukraine constantly ensure responsibilities. The goal in this case is ensuring changes in armed forces other countries, answering change of the forms and methods of warfighting, character of it, main principles and common changes in environment. In this context adequate evaluating the Armed Forces of Ukraine responsibilities in whole and responsibilities of the military organizational structures is important science task. Deciding of it needs in the responsibilities assessment contemporary methodic development.

Originality. The military education system must orient to concrete needs and tasks of functional sphere, ensuring the high level of professional training and qualification of military specialists in AF of Ukraine, other parts of safety and defense forces, that need using the new approaches for military education content forming with purpose of the achievement the high level of operational compatibility ensuring, interdepartmental interaction and coordination during the planning and making joint operations on the level of joint stabs according the standards and procedures of NATO. Taking this to account, the common principles are the part of methodic, base of it. Such principles are also base for organization and making the military organizational structures' responsibilities assessment on managerial level (assessment of management), system of criteria, and mechanism of the expert evaluate forming.

Conclusion. The proposals for methodic of the military organizational structures' responsibilities assessment can be ensuring for institutional review of the high military education institutions, in process of the methodical achievement development of it for needs of assessment the HMEI that are in the sphere of the MDU management. Assessment and institutional review can analyze really situation and make a conclusion about educational process organization in the system of professional military education, and also determine the level of the defense forces' contemporary needs satisfying in context of hybrid threats for national safety and integration of Ukraine to NATO. In this aspect the implementation of new conception of military education of Ukraine is important and will achieve the system of professional military education development, the harmonically unite the formal and unformal education in frame of common (joint) system of military education, that ensuring needed level of education and training of military specialists and officers for solving the tasks, which is call by today for AF of Ukraine. This process is making ability for acquisition of the operational responsibilities by the all parts of the safety and defense of state. In point of view the perspective of the law and normative ensuring the development connected with transit to NATO's standards that need making the politics and doctrines as regulators of process, purposes and responsibilities of the military education system in Ukraine.

Keywords: Armed Forces of Ukraine responsibilities, assessment, institutional review, methodic, military organizational structures. 